\title{
Interlinkage between Caribbean coral reefs and seagrass beds through feeding migrations by grunts (Haemulidae) depends on habitat accessibility
}

\author{
I. Nagelkerken ${ }^{1, *}$, J. Bothwell ${ }^{2}$, R. S. Nemeth ${ }^{3}$, J. M. Pitt ${ }^{4}$, G. van der Velde ${ }^{1,5}$ \\ ${ }^{1}$ Department of Animal Ecology and Ecophysiology, Institute for Wetland and Water Research, Faculty of Science, \\ Radboud University Nijmegen, Heyendaalseweg 135, PO Box 9010, 6500 GL Nijmegen, The Netherlands \\ ${ }^{2}$ Cayman Islands Department of Environment, PO Box 486, Grand Cayman KY1-1106, Cayman Islands \\ ${ }^{3}$ Center for Marine and Environmental Studies, University of the Virgin Islands, 2 John Brewers Bay, St. Thomas 00802-9990, \\ US Virgin Islands \\ ${ }^{4}$ Marine Environmental Program, Bermuda Institute of Ocean Sciences, 17 Biological Lane, Ferry Reach, St. George's GE 01, \\ Bermuda \\ ${ }^{5}$ National Museum of Natural History, Naturalis, PO Box 9517, 2300 RA Leiden, The Netherlands
}

\begin{abstract}
Tropical marine habitats are often energetically linked through feeding migrations by fish. A widely accepted assumption is that species of Haemulidae (grunts) undertake nocturnal feeding migrations from coral reefs to seagrass beds. This has been based on studies investigating migrations between small patch reefs and surrounding seagrass beds located in lagoons. Due to the size and location of these patch reefs, we argue that this does not represent migration from coral reef to seagrass ecosystems, and a literature search shows limited proof for such migration. We hypothesised that the spatial arrangement of these habitats in the seascape may have profound effects on the degree to which such migrations occur. Haemulon flavolineatum caught from seagrass beds located in semi-enclosed embayments, and thus isolated to a high degree from adjacent reefs, showed a diet and stable isotope signature of muscle tissue that differed from those collected from the coral reef. In contrast, fishes from open seagrass systems without restricted access from the reef showed the same stable isotope signature as those collected from the coral reef, suggesting feeding from the same habitat, viz. the seagrass beds. Additional visual census data showed that semi-enclosed seagrass beds did not have elevated densities of large-sized fish at night, which would be expected if large individuals from the reef migrated to the seagrass beds to feed. The data thus show that interlinkages between coastal ecosystems, such as coral reefs and seagrass beds, by fishes may strongly depend on the spatial arrangement of habitats within the seascape.
\end{abstract}

KEY WORDS: Haemulon flavolineatum - Coral reef - Seagrass · Feeding migrations - Habitat linkages $\cdot$ Stable isotopes $\cdot$ Diet analysis

\section{INTRODUCTION}

Mangroves, seagrass beds and coral reefs occur along many shallow-water tropical shorelines. These ecosystems are connected through physical, biological and chemical processes, including exchange of nutrients, organic matter, sediment, water bodies and animals (Parrish 1989, Lee 1995, Wolanski 2007). In particular, fish and decapods link these systems through spawning, feeding, tidal and ontogenetic migrations. Various shrimp and reef fish use mangroves and seagrass beds as juvenile habitats before migrating to offshore adult habitats (Manson et al. 2005, Nagelkerken 2007, Verweij et al. 2008). Many species also show consistent tidal or diurnal migrations between habitats, alternatively using them as shelter and feeding areas (Helfman et al. 1982, Vance et al. 1996, Nagelkerken \& van der Velde 2004, Verweij et al. 2006b). The scale, 
timing and duration of these migrations are highly variable, however, and depend on a variety of biotic and environmental factors. The arrangement of mangrove, seagrass and reef habitats within the seascape has profound effects on the degree and type of ecological linkages between these habitats, and affects the spatial distribution of fishes (Pittman et al. 2004, 2007, Dorenbosch et al. 2007, Grober-Dunsmore et al. 2007).

Seagrass beds are attractive juvenile habitats for various fish species because of the high abundance of food, lowered predation risk resulting from the high structural complexity of the habitat at the small scale, a lower number of predators and reduced water clarity compared to the reef (Parrish 1989, Verweij et al. 2006a). For similar reasons, many crustaceans and other macroinvertebrate fauna utilise seagrass beds as shelter habitats (Orth et al. 1984), providing potentially high food abundance to fishes. Seagrass beds have therefore been recognised as important feeding habitats for fishes in the Indo-Pacific (e.g. Kochzius 1999, Unsworth et al. 2007) as well as the Caribbean (e.g. Ogden \& Ehrlich 1977, Nagelkerken et al. 2000a), although most evidence comes from the latter region. Several studies have shown that fishes undertake nocturnal feeding migrations from structurally complex shelter habitats, such as mangroves, patch reefs, coral reefs, undercut notches and boulders, to more open habitats such as seagrass and algal beds (Ogden \& Ehrlich 1977, Helfman et al. 1982, McFarland \& Hillis 1982, Burke 1995, Nagelkerken et al. 2000a).

We tested whether the spatial arrangement of coral reefs relative to seagrass beds in the coastal seascape affects habitat linkages through feeding migrations by fishes. The reason for this is that there appears to be a discrepancy in the literature between the evidence and assumptions on feeding by reef fishes in seagrass beds. It is widely accepted that grunt species (Haemulidae), in particular Haemulon flavolineatum, $H$. plumieri and $H$. sciurus, undertake nocturnal feeding migrations from the reef to seagrass beds (e.g. Ogden \& Ehrlich 1977, Helfman et al. 1982, McFarland \& Hillis 1982). Reef habitats discussed in these studies are coral boulders or small patch reefs completely surrounded by seagrass beds and are all located within lagoons. Hence, they do not represent 'coral-reef-to-seagrass' migrations, but more so feeding migrations 'among back-reef habitats' located in the same lagoon. In the present study we argue that (1) there is little proof so far for true coral-reef-to-seagrass feeding migrations, (2) the studies that focused on feeding migrations to seagrass beds by grunts have been misinterpreted in many other studies and (3) nocturnal feeding in seagrass beds by Haemulidae from coral reefs depends on the degree of accessibility of the seagrass beds. Clearly, seagrass beds are attractive feeding sites for grunts if they surround small patch reefs that provide daytime shelter sites. Whether this is also true for spatially separated seagrass beds and patch or fringing reefs, or for seagrass beds that are less accessible to fishes, remains unclear.

We first review the literature for studies of nocturnal fish feeding migrations to seagrass beds in the Caribbean, and provide examples of studies that have misinterpreted these results. We only refer to studies that have directly investigated migration of fishes (i.e. based on observations of fish migration by e.g. visual observations or fish tagging), and not studies inferring between-habitat migrations based on differences in size frequencies of fishes or based on qualitative observations. Furthermore, we provide gut content, stable isotope and visual census survey data to support our hypothesis that nocturnal feeding in seagrass beds by Haemulon flavolineatum from adjacent coral reefs depends on the accessibility of the seagrass beds. We expect that for spatially isolated seagrass beds, feeding migrations by reef-associated grunts towards the seagrass beds are less pronounced than has thus far been observed.

\section{MATERIALS AND METHODS}

Study area. To test the effect of accessibility of seagrass beds on nocturnal feeding by Haemulon flavolineatum from coral reefs, 3 'open' and 3 'semi-enclosed' seagrass systems were selected at various islands in the Western Atlantic (Fig. 1). Open seagrass beds were defined as systems located adjacent to coral reefs without any barriers in between the 2 habitats (Bermuda; Grand Cayman, Cayman Islands; St. Thomas, US Virgin Islands), whereas semi-enclosed seagrass beds were defined as systems located in semi-enclosed lagoons or bays devoid of any patch reef development with only a narrow entrance connecting them to the adjacent coral reef (Aruba; Spanish Water Bay and Piscadera Bay in Curaçao, Netherlands Antilles). Semi-enclosed seagrass systems occur circumtropically, typically in areas where environmental conditions (e.g. water turbidity, salinity, temperature) in embayments or lagoons are suitable for seagrass growth but not for patch reef growth, such as Caribbean embayments in Belize, Bermuda, Bimini, Bonaire and Grand Cayman. Open systems, which are very prominent in the Indo-Pacific region, are found circumtropically in areas where the shallow-shelf area is large with clear and calm water, allowing for seagrass as well as coral reef growth.

In Bermuda, the study area was located within Castle Harbour, a semi-enclosed basin at the eastern end of the island (Fig. 1). Well-developed seagrass beds consisting of Thalassia testudinum and Syringodium 


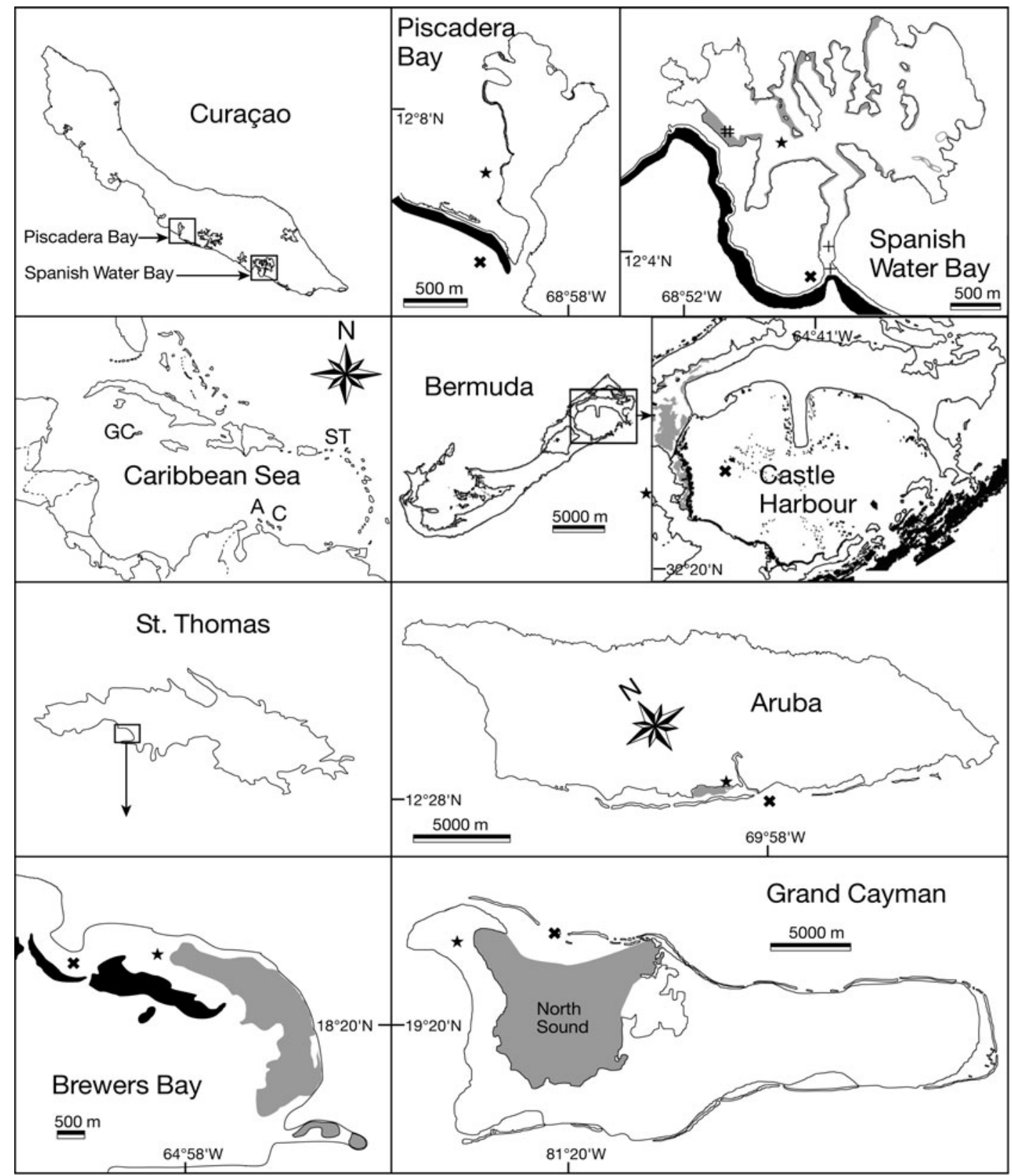

Fig. 1. Map of the study areas, showing the location of the seagrass beds (light grey), coral reefs (black), and fish collection sites $(\mathbf{x}=$ coral reef sites, $\star=$ seagrass sites). The continuous fringing coral reefs along the shorelines of Aruba and Grand Cayman are not shown. + = sites for visual census surveys on Curaçao. Fishes for which stable isotope analysis was done on the gut contents were collected at Spanish Water Bay from the sites marked with $\boldsymbol{x}$, , and \#. Inset Caribbean Sea: GC = Grand Cayman, A = Aruba, C= Curaçao, $\mathrm{ST}=$ St. Thomas. Bermuda is not shown on the inset but is located approx. $1540 \mathrm{~km}$ directly north of St. Thomas

filiforme occurred along the shallow western edge of the basin, which is bordered on the outside by a poorly developed fringing reef. There were numerous patch reefs scattered across the basin, and the large patch reef from which the samples were taken was located approximately $750 \mathrm{~m}$ from the nearest seagrass beds. The seagrass beds were separated from the patch reefs by bare sand at a depth of 6 to $9 \mathrm{~m}$.
In the Cayman Islands, the seagrass beds were located in the North Sound of Grand Cayman (Fig. 1). This is a large marine lagoon connected on its outer edge to an emergent fringing reef. The substratum of the southern three-quarters of the North Sound was covered by Thalassia testudinum with associated macroalgal species. The substratum of the northern quarter was covered by a mixture of sand, rock bottom 
and coral communities. The 'Wreck of the Pilot' seagrass collection site is a small wreck within a large area of $T$. testudinum, around which Haemulidae, Lutjanidae and other fish species congregated. The 'Barra Alley' reef site is a small channel through the emergent fringing reef with a small ledge along which Haemulon flavolineatum aggregated.

In St. Thomas, the seagrass beds located in Brewers Bay consisted of Syringodium filiforme mixed with sparse Thalassia testudinum. The seagrass and coral reef habitats were separated by a stretch of 100 to $400 \mathrm{~m}$ of bare sand (Fig. 1). At the east end of Brewers Bay, the coral reef consisted of large patch reefs at 4 to $6 \mathrm{~m}$ depth that merged to form a continuous fringing reef to the west.

In Aruba, the seagrass beds consisted of monospecific stands of Thalassia testudinum located in a shallow lagoon which was separated from the adjacent fringing reef by coral cays and a reef crest (Fig. 1). The open connection between the reef and the lagoon was about 0.5 to $4 \mathrm{~m}$ deep and about $450 \mathrm{~m}$ wide. The reef terrace was about $150 \mathrm{~m}$ wide and turned into a reef slope at 7 to $9 \mathrm{~m}$ depth up to a depth of about $25 \mathrm{~m}$, where a sandy plain started.

In Curaçao, the seagrass beds consisted of monospecific stands of Thalassia testudinum in Spanish Water Bay and of Syringodium filiforme in Piscadera Bay. The seagrass beds in each bay were connected to the reef by only a narrow channel. The mouth of Spanish Water Bay was about $85 \mathrm{~m}$ wide and $6 \mathrm{~m}$ deep, while the mouth of Piscadera Bay was about $70 \mathrm{~m}$ wide and $6 \mathrm{~m}$ deep (Fig. 1). The adjacent fringing coral reef started from the shore as a gradually sloping submarine terrace of about $150 \mathrm{~m}$ wide, until it reached the 'drop-off' at a depth of approximately 7 to $9 \mathrm{~m}$. At the drop-off, the reef sloped off steeply to about 50 to $60 \mathrm{~m}$ depth.

Sampling design. Although previous studies on grunt feeding migrations were carried out by following individual fishes (tagged or not tagged), we used stable isotope analysis of muscle tissue as an indicator of feeding migrations. The reason for this is that nocturnal fish feeding migrations or behaviour can be disturbed by using strobes during underwater surveys, and fish feeding may be difficult to observe in detail during night observations. By measuring stable isotopes in fish tissue, no effect of the methodology on fish migration or behaviour was present. At each reef site per island, 5 to 15 adult Haemulon flavolineatum ranging on average between 14.3 and $16.5 \mathrm{~cm}$ in fork length (FL) were collected at depths of 1.5 to $6 \mathrm{~m}$, while at each seagrass site per island 9 to 30 juveniles ranging on average between 8.1 and $8.9 \mathrm{~cm}$ FL were collected at depths of 0.5 to $2 \mathrm{~m}$ (Table 1). H. flavolineatum reaches adulthood from approximately $14 \mathrm{~cm}$ FL (Gaut \& Munro 1983). H. flavolineatum shows a strong ontogenetic shift in habitat use: juveniles are predominantly found in lagoonal habitats such as mangroves and seagrass beds, whereas adults mainly live and shelter on reefs at least during the daytime (Nagelkerken 2007). Hence, a comparison between adults from the 2 habitats was not possible. Sampling was carried out during daytime, in 1998 at Spanish Water Bay and 2001 to 2003 at the other localities. At each island the reef and seagrass fishes were collected simultaneously during the same time period.

For the stable isotope analysis, a small piece of muscle tissue was removed from each fish, dried for $48 \mathrm{~h}$ at $70^{\circ} \mathrm{C}$, and ground to a fine powder using a mortar, pestle and liquid nitrogen. Only muscle tissue was used because of its slow turnover rate, resulting in a history of food assimilation over periods of months and excluding short-term variability (Gearing 1991). Stable isotopes are well-suited to trace migrations of many animal species (see review by Hobson 1999). Carbon and nitrogen stable isotope compositions were measured with a Carlo Erba NA 1500 elemental analyser

Table 1. Haemulon flavolineatum. Sampling for stable isotope analysis. Length = mean fork length

\begin{tabular}{|c|c|c|c|c|c|}
\hline Island & Location & Sampling habitat & Sampling depth (m) & No. of fish sampled & Length $\pm \mathrm{SD}(\mathrm{cm})$ \\
\hline \multirow[t]{2}{*}{ Aruba } & \multirow[t]{2}{*}{ Mangel Alto } & Coral reef & $4-6$ & 5 & $14.3 \pm 1.3$ \\
\hline & & Seagrass bed & 0.5 & 10 & $8.2 \pm 0.7$ \\
\hline \multirow[t]{2}{*}{ Bermuda } & \multirow[t]{2}{*}{ Castle Harbour } & Coral reef & $2-4$ & 9 & $15.9 \pm 2.4$ \\
\hline & & Seagrass bed & 1 & 9 & $8.9 \pm 2.3$ \\
\hline \multirow[t]{4}{*}{ Curaçao } & \multirow[t]{2}{*}{ Piscadera } & Coral reef & $1.5-6$ & 15 & $15.3 \pm 1.0$ \\
\hline & & Seagrass bed & $0.5-2$ & 15 & $8.6 \pm 1.2$ \\
\hline & \multirow[t]{2}{*}{ Spanish Water Bay } & Coral reef & $4-6$ & 12 & $15.5 \pm 0.8$ \\
\hline & & Seagrass bed & $1-2$ & 30 & $8.1 \pm 1.5$ \\
\hline \multirow[t]{2}{*}{ Grand Cayman } & Barra Alley & Coral reef & 4.5 & 10 & $16.5 \pm 0.6$ \\
\hline & Wreck of the Pilot & Seagrass bed & 1.5 & 10 & $8.7 \pm 0.6$ \\
\hline \multirow[t]{2}{*}{ St. Thomas } & Brewer's Bay & Coral reef & $4-6$ & 10 & $15.4 \pm 1.2$ \\
\hline & & Seagrass bed & $1-2$ & 10 & $8.3 \pm 0.8$ \\
\hline
\end{tabular}


coupled on-line via a Finnigan Conflo III interface with a ThermoFinnigan DeltaPlus mass spectrometer. Carbon and nitrogen isotope ratios are expressed in the delta notation $\left(\delta^{13} \mathrm{C}, \delta^{15} \mathrm{~N}\right)$ relative to the Vienna PeeDee Belemnite standard and atmospheric nitrogen. Average reproducibilities based on replicate measurements of standards (acetanilide, ammonium sulphate, and sucrose) for $\delta^{13} \mathrm{C}$ and $\delta^{15} \mathrm{~N}$ were within $0.15 \%$.

For Curaçao, fish densities and diet data collected during earlier studies (Nagelkerken et al. 2000a) were also included to support the interpretation of the stable isotope data. Use of $>1$ method allows for stronger conclusions, and we therefore included these data from Curaçao even though they were not part of the original study design. Fish densities of Haemulon flavolineatum were estimated using visual census surveys during the daytime and at night in size classes of $2.5 \mathrm{~cm}$ at a reef site and seagrass site located $200 \mathrm{~m}$ from one another (Fig. 1). On the reef, 32 belt transects $(3 \times 50 \mathrm{~m})$ distributed over the 2, 5, 10 and $15 \mathrm{~m}$ reef depth zones were sampled during the daytime, while at night 16 transects were surveyed. In the seagrass bed, a total of 4 transects were sampled at night and 8 transects during the daytime. For further details see Nagelkerken et al. (2000a).

Gut contents of fish caught in Curaçao were studied for the same fish used in the stable isotope analysis. Fish analysed for the reef were larger in size than those from the seagrass beds due to the strong differences in ontogenetic habitat use by this species. To test for the effects of ontogeny in the comparison between the reef and seagrass beds we therefore additionally analysed gut contents for the largest size class of Haemulon flavolineatum that we could find in the seagrass bed (mean $\pm \mathrm{SD}: 12.7 \pm 0.3 \mathrm{~cm}$ FL; see Table 3 ). All fishes caught were immediately put on ice to avoid further food digestion. The entire digestive tract of each fish was removed and food items were quantified for the groups Amphipoda, Annelida, Bivalvia, Copepoda, Decapoda, Echinoidea, fish, Gastropoda, Isopoda, Mysidacea, sediment, Tanaidacea or unidentified. Diet composition was determined by estimating the relative volumetric quantity of food items, using a stereomicroscope.

During a consecutive field study in Curaçao in October 2007, we additionally collected gut contents of Haemulon flavolineatum for stable isotope analysis (Fig. 1) to confirm the different signatures of prey from the coral reef and seagrass food webs. We collected gut contents instead of living prey items, because it was difficult to (1) identify the specific prey species consumed from the gut contents, (2) identify the microhabitats where these prey species occurred and (3) sample these specific prey items due to their small size. Gut contents, on the other hand, reflect the true diet of the fishes and could thus indicate differences in stable isotope values of consumed prey items between habitats. Gut contents could only be collected in Curaçao at Spanish Water Bay. Fish measured $13.2 \pm 2.3 \mathrm{~cm}$ FL $($ mean $\pm \mathrm{SD})$ on the coral reef $(\mathrm{n}=18)$ and $9.6 \pm 1.1 \mathrm{~cm}$ on the seagrass beds $(\mathrm{n}=14)$. Gut contents were treated and analysed for stable isotope analysis in the same way as the tissue samples.

\section{RESULTS AND DISCUSSION}

\section{Current knowledge on nocturnal feeding migrations by Haemulidae}

Only a few studies have investigated nocturnal feeding migrations of Haemulidae to seagrass beds (Table 2). The majority of these were done in the US Virgin Islands and assessed various aspects of the nocturnal migration behaviour of Haemulidae sheltering during daytime on coral boulders or (small) patch reefs that were completely surrounded by seagrass beds within a lagoon. These studies showed that the feeding migrations are linked to changing light levels, are often precisely timed, and take place along fixed migration pathways, as much as $1 \mathrm{~km}$ long, which gradually bifurcate into a dendritic pattern with an individual fish at the tip of each branch. These studies from the 1970s and early 1980s (Table 2) have been widely cited in the literature as proof of the existence of nocturnal feeding migrations from coral reefs to seagrass beds (e.g. by Tulevech \& Recksiek 1994, Burke 1995, Kochzius 1999, Beets et al. 2003, Grober-Dunsmore et al. 2007, Unsworth et al. 2007), but in fact they report migrations from coral heads or small patch reefs located in lagoons to the directly surrounding seagrass beds within the same lagoon. The problem lies in the definition of a coral reef. Patch reefs located in seagrass beds within Caribbean lagoons are typically small areas of a few $\mathrm{m}^{2}$ to a few $100 \mathrm{~s}$ of $\mathrm{m}^{2}$ in size. They are not comparable to a coral reef ecosystem, which is an entity covering large surface areas in excess of $10 \mathrm{~s}$ to $100 \mathrm{~s}$ of $\mathrm{km}^{2}$ and functioning as a fairly independent ecosystem, such as atolls, and fringing and barrier reefs. Simply referring to 'reef to seagrass bed migration' based on results from patch reefs in lagoons leads to confusion.

True coral reef to seagrass migrations, i.e. between 2 ecologically and spatially separated coastal ecosystems, have not really been shown (Table 2). Burke (1995) and Beets et al. (2003) presented some preliminary data on the existence of nocturnal feeding migrations between spatially separated coral reefs and seagrass beds. Hence, the widely accepted idea that coral reef and seagrass ecosystems are energetically con- 


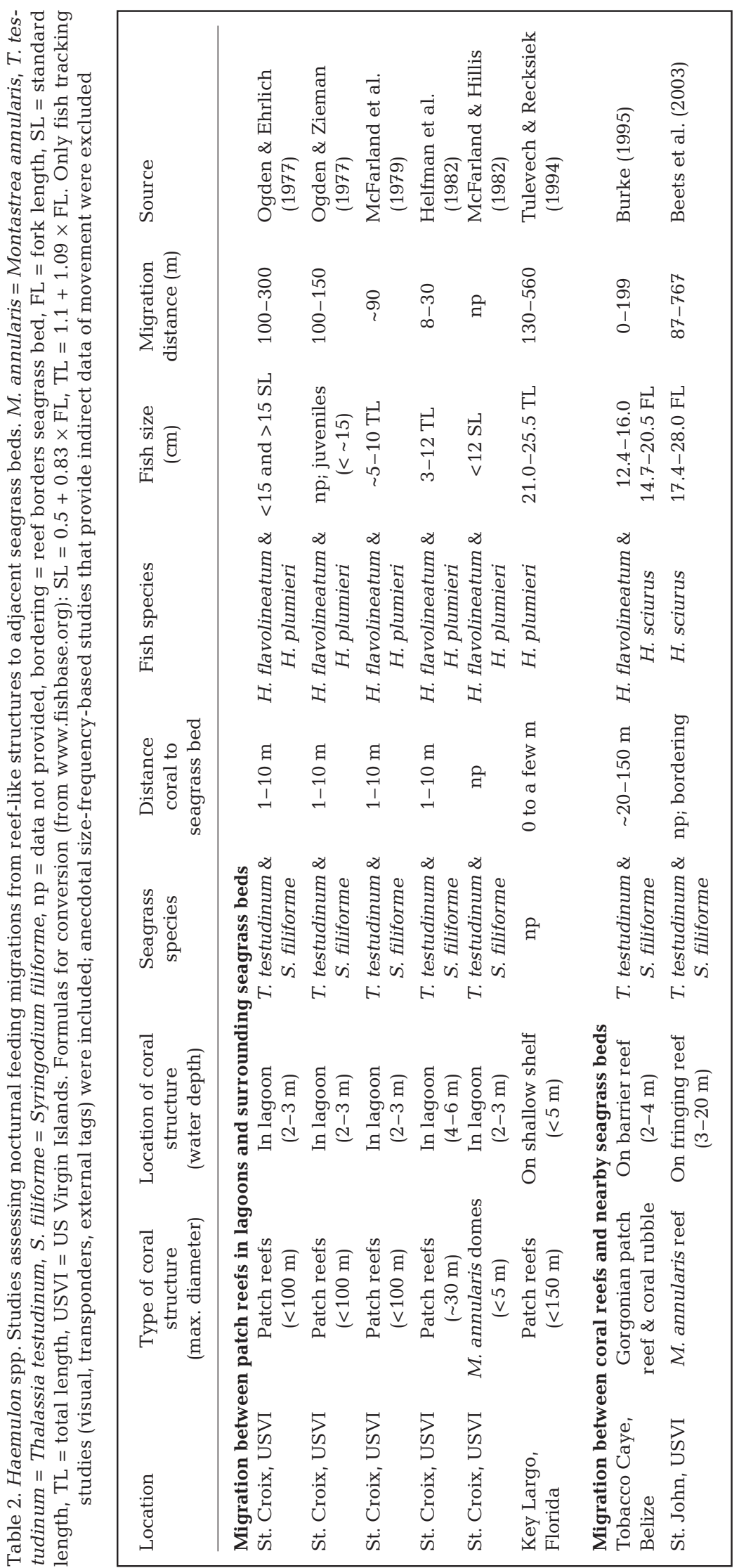

nected via fish feeding migrations should be re-evaluated by defining the type of reef that is referred to and by specifically designed experimental studies in order to gain a better understanding of migration between coral reef ecosystems and seagrass beds. Studies on this topic have largely been executed in the Caribbean. The few studies done so far in the Indo-Pacific were based on beach seine netting where the density data suggested nocturnal feeding migrations between coral reefs and seagrass beds by various fish species (Kochzius 1999, Unsworth et al. 2007).

\section{Effect of accessibility of seagrass beds on cross-habitat feeding migrations}

At island level, no significant difference in $\delta^{13} \mathrm{C}(\mathrm{p}>0.228, t$-test) was found for the 3 open seagrass systems between Haemulon flavolineatum from the seagrass beds and those from the adjacent coral reef (Fig. 2A). This indicates that the adult fish from the coral reef have a diet consisting of food items with a similar $\delta^{13} \mathrm{C}$ as those from the seagrass beds. As stable carbon isotope signatures of food items typically differ between coral reefs and seagrass beds (Fry et al. 1983, Hemminga et al. 1994), this suggests that $H$. flavolineatum from the reef and the seagrass beds feed in the same habitat, which in this case would be the seagrass beds because juvenile $H$. flavolineatum are not known to migrate from the seagrass beds to the reef for feeding.

For the semi-enclosed seagrass systems juvenile Haemulon flavolineatum from the seagrass bed were significantly depleted in $\delta^{13} \mathrm{C}(\mathrm{p}<0.013$, $t$-test) compared to the adults from the adjacent coral reef (Fig. 2B). The gut contents of fish collected at Spanish Water Bay showed the same pattern $(\mathrm{p}=0.046, t$-test $) ; \delta^{13} \mathrm{C}$ of gut contents were depleted by roughly $1 \%$ compared to that of the fish muscle tissues, which is a typical isotope fractionation between predator and prey (e.g. Fry 1988). The above clearly indicates that 

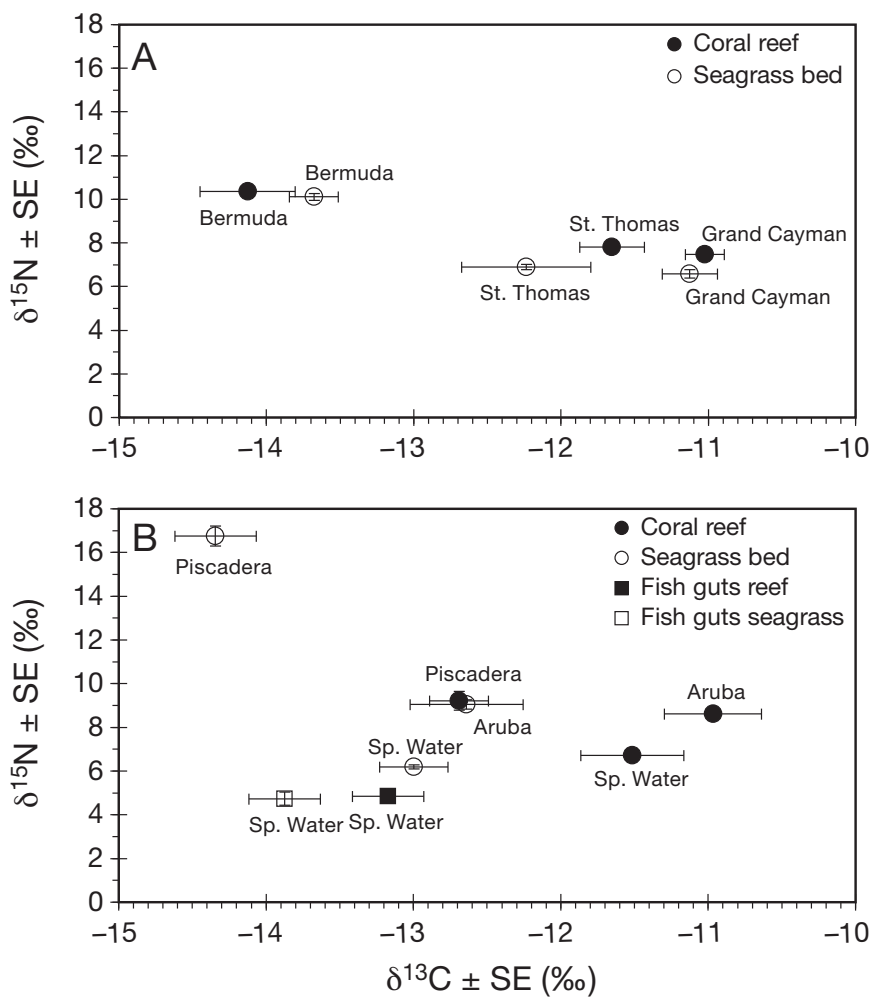

Fig. 2. Haemulon flavolineatum. Mean $\delta^{15} \mathrm{~N}$ and $\delta^{13} \mathrm{C}$ values for muscle tissue of fish collected on the coral reef, and on (A) 'open' seagrass beds versus (B) 'semi-enclosed' seagrass beds. For Spanish Water Bay (Sp. Water), mean stable isotope values are additionally shown for gut contents

individuals from the 2 habitats consume food sources with a different $\delta^{13} \mathrm{C}$, suggesting that they feed in different habitats. A difference in stable isotope signatures of prey items between the 2 habitats is supported in Curaçao by the different gut content signatures. The difference in diet is additionally supported by gut content data from Curaçao, where individuals from the reef fed primarily on Annelida, fish and Decapoda, whereas individuals from the seagrass bed mainly consumed Tanaidacea (Table 3). Although gut contents differed between large fish on the reef and mediumsized fish in the seagrass beds, ontogenetic shifts in $\delta^{13} \mathrm{C}$ and $\delta^{15} \mathrm{~N}$ can be ruled out as a factor causing the observed differences between stable isotope signatures on the reef versus the semi-enclosed seagrass beds. First, if stable isotope values were influenced by ontogeny then this effect would also be visible for the open seagrass systems, but here stable isotope values did not differ significantly between reef and seagrass beds, although different size classes were compared. Second, for none of the islands did $\delta^{15} \mathrm{~N}$ differ between different-sized fish from the 2 habitat types (for both open and closed systems), indicating that they act at the same trophic level. An exception was a much higher $\delta^{15} \mathrm{~N}$ value for medium-sized seagrass fishes in the eutrophicated Piscadera Bay than for large fish from the coral reef, which is opposite to the usual increase in trophic level for adult fish (e.g. Jennings et al. 2002).

The absence of feeding in semi-enclosed seagrass beds by adults from the coral reef in this setting is further supported by size frequency data of Haemulon flavolineatum from both habitats during day and night in Curaçao (Fig. 3). First, no increase in fish density was observed in the seagrass beds at night compared to daytime, which could have been caused by individuals migrating from the coral reef to the seagrass beds. Second, the larger size classes $(10$ to $20 \mathrm{~cm})$, which likely possess a larger home range than the small individuals, were completely absent from the seagrass beds but remained present on the coral reef by day and night. The distance between the reef and the seagrass beds could not have played a major role because the sampled seagrass beds in the mouth of the Spanish Water Bay were located about $200 \mathrm{~m}$ away from the coral reef, and Haemulidae are known to undertake nocturnal feeding migrations up to $1 \mathrm{~km}$ (Ogden \& Zie-

Table 3. Haemulon flavolineatum. Gut content (\% volume) analysis from the Spanish Water Bay area, for adults from the coral reef and for juveniles from the seagrass bed (see Table 1), and additionally for large individuals (mean fork length \pm SD: $12.7 \pm$ $0.3 \mathrm{~cm}$ ) from the seagrass beds. Values in bold indicate a relative identifiable food abundance of $>10 \%$ in the gut. Amphi $=$ Amphipoda, Anne $=$ Annelida, Bival $=$ Bivalvia, Cope $=$ Copepoda, Deca $=$ Decapoda, Echino $=$ Echinoidea,

Gastro $=$ Gastropoda, Iso $=$ Isopoda, Mysi $=$ Mysidacea, Sed $=$ sediment, Tana $=$ Tanaidacea, Unid $=$ unidentifiable

\begin{tabular}{|c|c|c|c|c|c|c|c|c|c|c|c|c|c|c|}
\hline $\begin{array}{l}\text { Location, } \\
\text { type of fish }\end{array}$ & $\mathrm{n}$ & Amphi & Anne & Bival & Cope & Deca & Echino & Fish & Gastro & Iso & Mysi & Sed & Tana & Unid \\
\hline $\begin{array}{c}\text { Coral reef, } \\
\text { large fish }\end{array}$ & 12 & 4 & 27 & 3 & 2 & 12 & 2 & 18 & 6 & 2 & 1 & 20 & 0 & 1 \\
\hline $\begin{array}{l}\text { Seagrass bed, } \\
\text { juveniles }\end{array}$ & 30 & 1 & 0 & 0 & 0 & 11 & 0 & 3 & 6 & 0 & 0 & 13 & 39 & 26 \\
\hline $\begin{array}{l}\text { Seagrass bed, } \\
\text { large fish }\end{array}$ & 6 & 0 & 3 & 0 & 0 & 0 & 0 & 0 & 0 & 0 & 0 & 0 & 55 & 41 \\
\hline
\end{tabular}




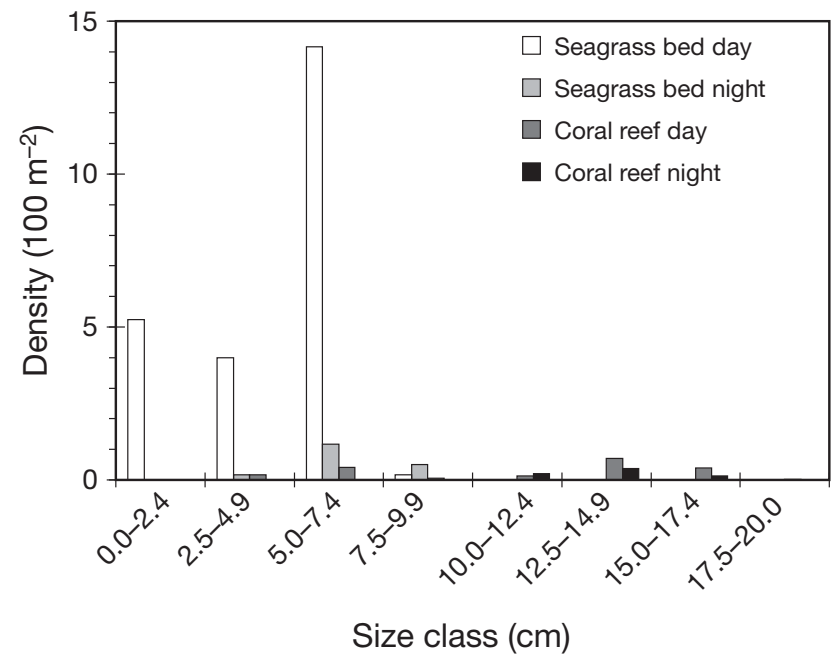

Fig. 3. Haemulon flavolineatum. Density distribution for different size classes (fork length [FL]) on the seagrass beds and coral reef in the Spanish Water Bay area, at night and during the daytime

man 1977; Table 2). The restricted width and depth of the channels connecting the coral reefs to the lagoon in Aruba and the 2 bays in Curaçao (Fig. 1), respectively, may reduce the likelihood of reef individuals finding and entering the seagrass beds compared to open seagrass systems. Hence, the larger the interface is between the reef and the adjacent seagrass beds, the higher the number of fish which may find and migrate to the seagrass beds.

One might argue that adult Haemulon flavolineatum from the reef do feed in semi-enclosed seagrass systems, but consume food items with a different $\delta^{13} \mathrm{C}$ than the juveniles in the seagrass beds, resulting in the observed difference in $\delta^{13} \mathrm{C}$ between individuals from the reef and those from the seagrass beds. This argument can be discarded on the basis of 3 different observations. First, large juvenile $H$. flavolineatum (mean length: $12.7 \mathrm{~cm}$, range: 12.3 to $13.0 \mathrm{~cm}$ ) resident in the seagrass beds of Spanish Water Bay primarily consumed Tanaidacea, just as the mediumsized juveniles (mean: $8.1 \mathrm{~cm}$, range: 5.8 to $11.0 \mathrm{~cm}$ ) in the seagrass beds did, whereas adult individuals (mean: $15.5 \mathrm{~cm}$, range: 14.4 to $16.7 \mathrm{~cm}$ ) on the coral reef never consumed Tanaidacea (Table 3). The similarity in diet between medium- and large-sized individuals from the seagrass beds suggests that primary feeding on Tanaidacea does not change through ontogeny as long as the fish are residing in the seagrass beds. On the coral reef they must depend on other food items as Tanaidacea occur in low abundances there: 5 vs. 229 Tanaidacea $\mathrm{dm}^{-3}$ in the substratum, and 2 vs. 1172 Tanaidacea $\mathrm{m}^{-3}$ in the water layer above the substratum, on the reef and seagrass beds, respectively (I. Nagelkerken unpubl. data). Hence, large individuals collected on the reef would be expected to show a diet largely based on Tanaidacea (just as the large individuals collected on the seagrass beds), should they indeed feed on the seagrass beds at night. However, their diet did not include a single specimen of Tanaidacea. Second, Piscadera Bay is highly eutrophicated with sewage effluent overflow from the nearby municipal sewage treatment plant at Klein Hofje (Buth \& Ras 1992), which caused the highly enriched $\delta^{15} \mathrm{~N}$ values of juveniles in the seagrass beds of the bay compared to the fish from the reef (Fig. 2B). When marine habitats are eutrophicated by sewage effluents, nearly the entire food web is enriched in $\delta^{15} \mathrm{~N}$ (e.g. Schlacher et al. 2005). Hence, independent of what specific food items the individuals from the reef consume, their significant depletion of $7.6 \%$ in $\delta^{15} \mathrm{~N}$ ( $\mathrm{p}<0.001, t$-test) compared to the individuals from the seagrass beds of Piscadera Bay shows that they do not consume any food from the seagrass beds or other bay habitats, as this would have resulted in an enrichment in $\delta^{15} \mathrm{~N}$ for the reef individuals. Third, it has been shown worldwide that stable carbon signatures of food webs typically differ between coral reefs and seagrass beds (Fry et al. 1983, Hemminga et al. 1994), which would explain the observed difference in $\delta^{13} \mathrm{C}$ between fish from, and foraging within, different habitat types. The effect of seasonality on feeding and stable isotope values was not investigated here, but samples for seagrass-reef comparisons were taken at the same time for the various study locations.

The present study demonstrates that the spatial arrangement of habitats is an important factor influencing their ecological linkages. Distance to other habitats and patch size affect the composition of tropical coastal fish communities (Dorenbosch et al. 2007, Grober-Dunsmore et al. 2007). Likewise, distance to coral reefs seems to affect the fish assemblage of seagrass beds significantly (Weinstein \& Heck 1979, Nagelkerken et al. 2000b). This means that resource management should be based on managing habitat mosaics and their configuration rather than single habitats. This is important for management-related issues such as location and size selection of marine protected areas (MPAs).

In conclusion, the present study suggests that the degree of accessibility of the seagrass beds determines the degree to which adult Haemulon flavolineatum, and possibly other fish species, migrate from coral reefs to adjacent seagrass beds to feed. The configuration of habitat patches within a seascape influences their degree of interlinkage by fish migration, affects fish migration patterns, and has a strong impact on the feeding ecology of reef fishes. 
Acknowledgements. We thank J. Eygensteyn for analysing the stable isotopes, J. de Brouwer, M. Dorenbosch, M. G. G. Grol, C. M. Huijbers, W. C. E. P. Verberk, M. G. Versteeg and the Department of Agriculture and Fisheries on Aruba for logistic support. I.N. was funded by a Vidi grant from the Netherlands Organisation of Scientific Research (NWO). Support to R.S.N. for preparation of this publication was provided by the Virgin Island-Experimental Program to Stimulate Competitive Research (VI-EPSCoR) programme under National Science Foundation (NSF) grant no. 0346483. Any opinions, findings, conclusions or recommendations expressed in this paper are those of the authors and do not necessarily reflect the official views of the NSF. This is Centre for Wetland Ecology publication no. 487. The Bermuda samples were collected under permit SP030501 from the Bermuda Government Department of Environmental Protection, Marine Resources Division.

\section{LITERATURE CITED}

Beets J, Muehlstein L, Haught K, Schmitges H (2003) Habitat connectivity in coastal environments: patterns and movements of Caribbean coral reef fishes with emphasis on bluestriped grunt, Haemulon sciurus. Gulf Caribb Res 14: 29-42

Burke NC (1995) Nocturnal foraging habitats of French and bluestriped grunts Haemulon flavolineatum and H. sciurus, at Tobacco Caye, Belize. Environ Biol Fishes 42:365-374

Buth L, Ras J (1992) Inventory of the land-based sources of marine pollution, Netherlands Antilles. RZZ (Council for Sea Research and Sea Activities), Curaçao

Dorenbosch M, Verberk WCEP, Nagelkerken I, van der Velde G (2007) Influence of habitat configuration on connectivity between fish assemblages of Caribbean seagrass beds, mangroves and coral reefs. Mar Ecol Prog Ser 334:103-116

Fry B (1988) Food web structure on Georges Bank from stable C, N, and S isotopic compositions. Limnol Oceanogr 33: $1182-1190$

Fry B, Scalan RS, Parker PL (1983) ${ }^{13} \mathrm{C} /{ }^{12} \mathrm{C}$ ratios in marine food webs of the Torres Strait, Queensland. Aust J Mar Freshw Res 34:707-715

Gaut VC, Munro JL (1983) The biology, ecology and bionomics of the grunts, Pomadasyidae. In: Munro JL (ed) Caribbean coral reef fishery resources. ICLARM studies and reviews 7. International Center for Living Aquatic Resources Management, Manila, p 110-141

Gearing JN (1991) The study of diet and trophic relationships through natural abundance ${ }^{13} \mathrm{C}$. In: Coleman DC, Fry B (eds) Carbon isotope techniques. Academic Press, San Diego, CA, p 201-218

Grober-Dunsmore R, Frazer TK, Lindberg WJ, Beets J (2007) Reef fish and habitat relationships in a Caribbean seascape: the importance of reef context. Coral Reefs 26:201-216

Helfman GS, Meyer JL, McFarland WN (1982) The ontogeny of twilight migration patterns in grunts (Pisces: Haemulidae). Anim Behav 30:317-326

Hemminga MA, Slim FJ, Kazungu J, Ganssen GM, Nieuwenhuize J, Kruyt NM (1994) Carbon outwelling from a mangrove forest with adjacent seagrass beds and coral reefs (Gazi Bay, Kenya). Mar Ecol Prog Ser 106:291-301

Hobson KA (1999) Tracing origins and migration of wildlife using stable isotopes: a review. Oecologia 120:314-326

> Jennings S, Pinnegar JK, Polunin NVC, Warr KJ (2002) Linking size-based and trophic analyses of benthic community structure. Mar Ecol Prog Ser 226:77-85

Kochzius M (1999) Interrelation of ichthyofauna from a sea- grass meadow and coral reef in the Philippines. In: Séret B, Sire JY (eds) Proc 5th Indo-Pac Fish Conf, 3-8 November 1997, Nouméa. Société Française d'Ichtyologie/Institut de Recherche par le Développement, Paris, p 517-535

> Lee SY (1995) Mangrove outwelling: a review. Hydrobiologia 295:203-212

Manson FJ, Loneragan NR, Skilleter GA, Phinn SR (2005) An evaluation of the evidence for linkages between mangroves and fisheries: a synthesis of the literature and identification of research directions. Oceanogr Mar Biol Annu Rev 43:483-513

McFarland WN, Hillis ZM (1982) Observations on agonistic behavior between members of juvenile french and white grunts - family Haemulidae. Bull Mar Sci 32:255-268

McFarland WN, Ogden JC, Lythgoe JN (1979) The influence of light on the twilight migrations of grunts. Environ Biol Fishes 4:9-22

Nagelkerken I (2007) Are non-estuarine mangroves connected to coral reefs through fish migration? Bull Mar Sci 80:595-607

- Nagelkerken I, van der Velde G (2004) Relative importance of interlinked mangroves and seagrass beds as feeding habitats for juvenile reef fish on a Caribbean island. Mar Ecol Prog Ser 274:153-159

> Nagelkerken I, Dorenbosch M, Verberk WCEP, Cocheret de la Morinière E, van der Velde G (2000a) Day-night shifts of fishes between shallow-water biotopes of a Caribbean bay, with emphasis on the nocturnal feeding of Haemulidae and Lutjanidae. Mar Ecol Prog Ser 194:55-64

Nagelkerken I, Dorenbosch M, Verberk WCEP, Cocheret de la Morinière E, van der Velde G (2000b) Importance of shallow-water biotopes of a Caribbean bay for juvenile coral reef fishes: patterns in biotope association, community structure and spatial distribution. Mar Ecol Prog Ser 202:175-192

> Ogden JC, Ehrlich PR (1977) The behavior of heterotypic resting schools of juvenile grunts (Pomadasyidae). Mar Biol 42:273-280

Ogden JC, Zieman JC (1977) Ecological aspects of coral reefseagrass bed contacts in the Caribbean. Proc 3rd Int Coral Reef Symp 1:377-382

Orth RJ, Heck KL, van Montfrans J (1984) Faunal communities in seagrass beds: a review of the influence of plant structure and prey characteristics on predator-prey relationships. Estuaries 7:339-350

- Parrish JD (1989) Fish communities of interacting shallowwater habitats in tropical oceanic regions. Mar Ecol Prog Ser 58:143-160

Pittman SJ, McAlpine CA, Pittman KM (2004) Linking fish and prawns to their environment: a hierarchical landscape approach. Mar Ecol Prog Ser 283:233-254

Pittman SJ, Caldow C, Hile SD, Monaco ME (2007) Using seascape types to explain the spatial patterns of fish in the mangroves of SW Puerto Rico. Mar Ecol Prog Ser 348: 273-284

Schlacher TA, Liddell B, Gaston TF, Schlacher-Hoenlinger M (2005) Fish track wastewater pollution to estuaries. Oecologia 144:570-584

Tulevech SM, Recksiek CW (1994) Acoustic tracking of adult white grunt, Haemulon plumieri, in Puerto Rico and Florida. Fish Res 19:301-319

Unsworth RKF, Wylie E, Smith DJ, Bell JJ (2007) Diel trophic structuring of seagrass bed fish assemblages in the Wakatobi Marine National Park, Indonesia. Estuar Coast Shelf Sci 72:81-88

> Vance DJ, Haywood MDE, Heales DS, Kenyon RA, Loneragan NR, Pendrey RC (1996) How far do prawns and fish 
move into mangroves? Distribution of juvenile banana prawns Penaeus merguiensis and fish in a tropical mangrove forest in northern Australia. Mar Ecol Prog Ser 131: 115-124

> Verweij MC, Nagelkerken I, de Graaff D, Peeters M, Bakker EJ, van der Velde G (2006a) Structure, food and shade attract juvenile coral reef fish to mangrove and seagrass habitats: a field experiment. Mar Ecol Prog Ser 306: $257-268$

Verweij MC, Nagelkerken I, Wartenbergh SLJ, Pen IR, van der Velde G (2006b) Caribbean mangroves and seagrass

Editorial responsibility: Matthias Seaman,

Oldendorf/Luhe, Germany beds as daytime feeding habitats for juvenile French grunts, Haemulon flavolineatum. Mar Biol 149:1291-1299

Verweij MC, Nagelkerken I, Hans I, Ruseler SM, Mason PRD (2008) Seagrass nurseries contribute to coral reef fish populations. Limnol Oceanogr 53:1540-1547

Weinstein MP, Heck KL (1979) Ichthyofauna of seagrass meadows along the Caribbean coast of Panamá and in the Gulf of Mexico: composition, structure and community ecology. Mar Biol 50:97-107

Wolanski E (2007) Estuarine ecohydrology. Elsevier Science, Amsterdam

Submitted: April 19, 2007; Accepted: April 16, 2008

Proofs received from author(s): September 11, 2008 